\title{
Navel Orangeworm (Lepidoptera: Pyralidae) Intercepted on Fresh Oranges from the USA at the Korean Port of Entry
}

\author{
Ki-Jeong Hong*, Seongwook Hong ${ }^{1}$, Changseok Ryu ${ }^{1}$ and Yonghyun Lee ${ }^{2}$ \\ Plant Quarantine Technology Center, Animal Plant and Fisheries Quarantine and Inspection Agency, Suwon 443-400, Korea \\ ${ }^{1}$ Busan Newport District Office, Animal Plant and Fisheries Quarantine and Inspection Agency, Busan 618-410, Korea \\ ${ }^{2}$ Yeongnam Regional Office, Animal Plant and Fisheries Quarantine and Inspection Agency, Busan 600-016, Korea
}

\section{미국산 오롄지 생교실에서 검출된 Navel Orangeworm (나비목: 명나방과)}

\author{
홍기정* · 홍성욱 $\cdot$ 류창석 ${ }^{1} \cdot$ 이용현 ${ }^{2}$ \\ 농림수산검역검사본부 식물검역기술개발센터, ${ }^{1 ㄴ ㅗ ㅇ ㄹ ㅣ ㅁ ㅅ ㅜ ㅅ ㅏ ㄴ ㄱ ㅓ ㅁ ㅇ ㅕ ㄱ ㄱ ㅓ ㅁ ㅅ ㅏ ㅂ ㅗ ㄴ ㅂ ㅜ ~ ㅂ ㅜ ㅅ ㅏ ㄴ ㅅ ㅣ ㄴ ㅎ ㅏ ㅇ ㅅ ㅏ ㅁ ㅜ ㅅ ㅗ, ~}{ }^{2}$ 농림수산검역검사본부 영남지역본부
}

\begin{abstract}
Navel orangeworm, Amyelois transitella (Walker) was intercepted at the Korean port of entry. It was detected by an inspection for a consignment of fresh oranges from the USA by the Busan Newport District Office, Yeongnam regional office, Animal Plant and Fisheries Quarantine and Inspection Agency on January 31, 2012. This is the first time that the larvae of this pest species has been detected on fresh oranges, although it has been occasionally detected on walnuts. This report aims to ensure biosecurity by providing diagnostic characters to identify the caterpillars and conducting an imported risk analysis on fresh oranges from the USA.
\end{abstract}

Key words: Navel orangeworm, Amyelois transitella, Orange, USA, Plant quarantine, Intercepted

초 록: 2012년 1월 31일 농림수산검역검사본부 영남지역본부 부산신항사무소에서 미국산 오렌지 생과실 화물을 검사하는 과정에서 Navel orangeworm, Amyelois transitella (Walker)이 검출되었다. 이 해충의 유충이 간혹 호두 과실 속에서 검출된 예가 알려져 있지만, 오렌지 생과실 속에서 검출된 경우는 처음이다. 여기서는 식물검역의 안전성을 보장할 목적으로 이 유충의 진단형질 및 미국산 오렌지 생과실에 대한 병해충수입 위험분석과 관련된 검출정보를 제공하고자 한다.

검색어: Amyelois transitella, 오렌지, 미국, 식물검역, 검출

The consignment $(18,615 \mathrm{~kg})$ of fresh oranges from USA was inspected at Korean port of entry by Busan newport district office, Yeongnam regional office, Animal Plant and Fisheries Quarantine and Inspection Agency (QIA) on January 31st, 2012. A total of four live larvae were detected by cutting the oranges with suspicious symptoms (Fig. 1a, b). They were identified as navel orangeworm, Amyelois transitella (Walker, 1863). Navel orangeworm has been designated as a quarantine pest in Korea.

*Comesponding author: stpeters@korea.kr

Received March 8 2012; Revised June 152012

Accepted July 52012
Navel orangeworm, Amyelois transitella (Walker) is a moth of the Pyralidae family. It is native to the southwestern United States and Mexico (Bartlett, 1979) and feeds within mature fruit of host, preferring the injured or diseased fruit. It is an important pest of nuts: almond, Prunus dulcis (Mill.); walnut, Juglans regia L.; and pistachio, Pistacia vera L. with the hull split. As sites for navel orangeworm development, sunburned nuts may be susceptible to navel orangeworm attack when the hull tissue is sufficiently damaged to allow the larval entry (Shelton and Davis, 1994). And, this pest is primarily a scavenger that breeds in at least 25 species of mummified fruits and nuts such as fig, Ficus carica L.; pomegranate, Punica granatum L.; orange, 
Citrus spp.; grapefruit, Citrus $\times$ paradise Macfad.; apple, Malus domestica Borkh.; peach, Prunus persica (L.) Batsch; plum, Prunus domestica L.; date palm, Phoenix dactylifera L.; grapevine, Vitis vinifera L.; pecan, Carya illinoensis (Wangenh.) Koch and honey locust, Gleditsia triacanthos L. (Hill, 1983; Stehr, 1987).

Although the larvae of this pest have been occasionally detected on the fruits of walnut (import prohibited item owing to codling moth) in Japan (Yoshida et al., 1989; Choi et al., 1996), probably the detection from the fresh orange is the first time. Likewise, the detection of egg masses of Fuller's rose weevil, Pantomorus cervinus (Boheman) has been increased after the exemption of mandatory fumigation by Methyl Bromide on the fresh oranges from the USA since November, 2010. The egg mass of Fuller's rose weevil has been detected on the stalk part of fruit, which is triggering the further new risk mitigation options alternative to the Methyl Bromide fumigation between USA and Korea. Therefore, this report aims to ensure biosecurity by providing diagnostic characters to identify the caterpillars and conducting an Imported Risk Analysis (IRA) on the fresh oranges from the USA.

\section{Diagnostics}

Egg. Opaque white when first laid. After about a day, pink then reddish orange (UC IPM, 2012).

Larva(Fig. 1c-g). Full-grown larva ranges from 13 to $19 \mathrm{~mm}$ in length. Young worms reddish orange and, after the first moult, pinkish orange to cream colored, although their diet can influence coloration (Walker, 2005). Head pale brown to dark brown with relatively indistinct pale brown, pale orange or black platelets; head frequently also with other indistinct pigmentation overlaying platelets with a mottled appearance, and with a distinct dark brown to black steak at posterior margin. Cornal suture absent. T1 behind head with a pair of crescentshaped markings and with 2 setae before prespiracle (Fig. 1d). T2, T3 and abdomen mostly yellowish white. Pinacula pale brown to brown. SD1 of T2 and A8 with pale brown to dark brown pinacula rings (Fig. 1e, f). SD1 of A1-A7 also usually partially encircled with pale brown to dark brown ring fragments (appearing as small, faint, brown patches at base of SD1 in many preserved specimens). SD2 of A8 usually separated from the spiracle by one to 1.5 times the diameter of the spiracle (Fig. 1f). A3-6 crochets biordinal in ellipses (Fig. 1g) (Weisman, 1986; Stehr, 1987; Choi et al., 1996).

Pupa. Light to dark brown, with sutures clearly evident, encased in a woven cocoon, and found inside nits or between hulls and shells. They range from 7.25 to $12 \mathrm{~mm}$ in length, those of the females averaging larger (Walker, 2005; UC IPM, 2012).

Adult. Wingspan about $2.5 \mathrm{~cm}$ long, body length average 10.9 $\mathrm{mm}$ in female and $9.7 \mathrm{~mm}$ in male. Forewings predominately gray with irregular black markings, and with a snoutlike projection in front of the head help distinguish this moth from the codling moth. Hindwings uniformly light, except for a darkening at the tips and along the veins (Walker, 2005; UC IPM, 2012).

Damage: First instar larvae of navel orangeworm bore into the nutmeat with small, pinhole-size entrances and later instars can consume most of the nut, producing large amounts of webbing and frass. Usually more than one larva can be found feeding in a nut. Larval damage can also lead to fungal infections. Some cultivars of almond are more susceptible to damage, especially later maturing, softshell almonds with a lengthy hull split period or a poor shell seal. Infested pistachios will split early and can usually be seen by mid-July. Infested walnuts only by the navel orangeworm may show no external signs of webbing or frass, but shells of heavily infested nuts will have an oily appearance (UC IPM, 2012).

Biology: Navel orangeworm overwinters as larvae inside mummy nuts on the tree and in the trash nuts left on the ground and around hullers. Pupation begins in March and may continue through the early May. Moths of the overwintered brood start to emerge in April, and the peak emergence usually occurs from late April to mid-May, depending on season and locality. Females begin egg laying about 2 nights after emergence. Eggs are laid singly on mummy nuts, codling moth-infested nuts, or blighted nuts in the trees or on the new crop nuts after the initiation of hull split. The first generation, and most of the second, is completed in these nuts. In late summer, some of the second generation larvae infest the new crop as the husks begin to split. Females emerging at this time prefer to lay eggs on the opened husk or on the exposed nutshell. After hatching within 4 

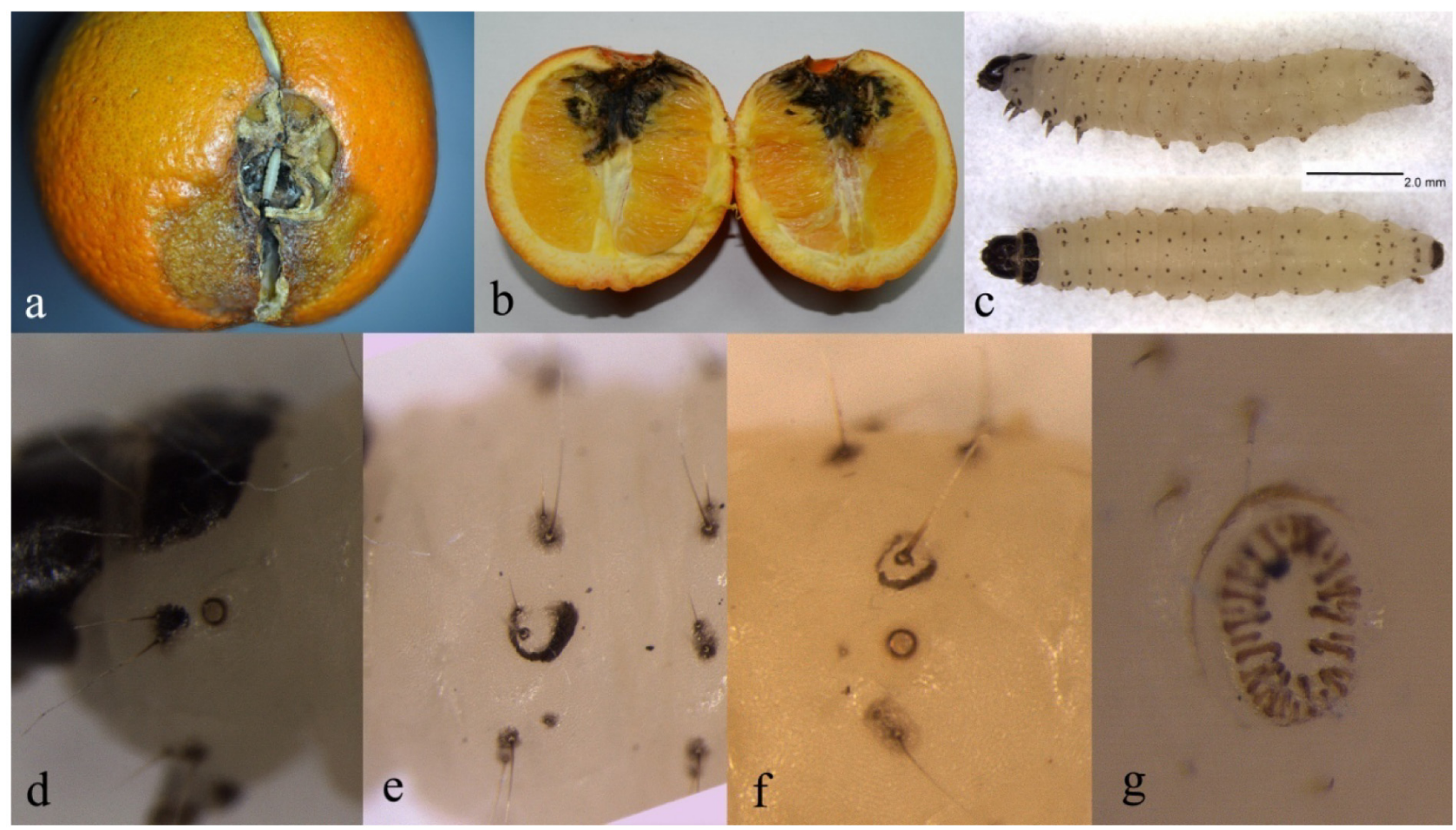

Fig. 1. Navel orangeworm, Amyelois transitella (Walker), intercepted on fresh oranges from the USA; a: orange with symptoms of suspected infestation; b: live larva of moth by checking an incision in the fruit; c: larva; $d$ : two setae before prespiracle on T1; e: pinacula ring around SD1 on T2; f: pinacula ring around SD1, SD2 and spiracle on A8; g: biordinal crochet of A5.

to 23 days depending on temperature, the tiny caterpillars enter nuts through the soft tissue at the stem end and do not emerge until they become adults. Several larvae may infest one nut and produce substantial webbing. In contrast, only a single codling moth is found in each nut, and the codling moth produces little webbing (UC IPM, 2012). Between three and five overlapping generations of navel orangeworm occur each year in California nut crops. The insect has no diapause and is active all year if conditions are favorable (Shelton and Davis, 1994).

\section{Literature Cited}

Bartlett, B.R. 1979. Introduced parasites and predators of arthropod pests and weeds: A world review. Agricultural Handbook No. 480, 545 pp. USDA-ARS, Washington, DC.

Hill, D.S. 1983. Agricultural insect pests of the tropics and their control. $2^{\text {nd }}$ ed., 746 pp. Cambridge University Press.

Choi, G.M., M.H. Lee, M.J. Han, S.B. Ahn and K.J. Hong. 1996. Stored product insect pests with pictorial key to larvae. 227 pp. National Institute of Agricultural Sciences and Technology. Sammi Publishing Company.
Shelton, M.D. and D.W. Davis. 1994. Navel Orangeworm (Lepidoptera: Pyralidae) Development in Sunburned Walnuts. J. Econ. Entomol. 87(4): 1062-1069.

Stehr, F.W. 1987. 26. Order Lepidoptera. In Immature insects, ed. by F.W. Stehr, 1987. 754 pp. Kendall/Hunt Publishing Company, Dubuque, Iowa.

UC IPM. 2012. UC Pest management guidelines: Almond, Pistachio and Walnut-Navel orangeworm. UC ANR(University of California Agriculture \& Natural Resources) Publication 3431, 3461 and 3471. http://www.ipm.ucdavis.edu/PMG/crops-agriculture.html [accessed 9-Feb-2012].

Walker, K. 2005. Navel orangeworm (Amyelois transitella). Available online: PaDIL -http://www.padil.gov.au/ [accessed 9-Feb-2012].

Weisman, D.M. 1986. Keys for the identification of some frequently intercepted lepidopterous larvae. U.S. Dept. Agr. APHIS 81-47.

Yoshida, T., N. Watanabe and M. Sonda. 1989. Pictorial guide to insect pests of stored food products. $268 \mathrm{pp}$. Zenkoku Nosen Kyoiku Kyokai Publishing Co. Ltd., Tokyo. 